\section{International Scientific Journal Theoretical \& Applied Science}

p-ISSN: 2308-4944 (print) e-ISSN: 2409-0085 (online)

Year: 2015 Issue: 07 Volume: 27

Published: $30.07 .2015 \quad$ http://T-Science.org
Denis Alexandrovich Chemezov

Master of Engineering and Technology, Corresponding member of International Academy of

Theoretical and Applied Sciences, Lecturer of Vladimir Industrial College, Russia chemezov-da@yandex.ru

SECTION 7. Mechanics and machine construction.

\title{
COMPARATIVE ANALYSIS OF STRESS-STRAIN STATE OF WORKPIECES MADE OF ALUMINIUM ALLOY DURING OF THE EQUAL CHANNEL ANGULAR PRESSING PROCESS ACCORDING TO DIFFERENT SCHEMES
}

Abstract: This article presents a comparative analysis of the results of computer simulation in software LSDYNA of the process of equal channel angular pressing process of the workpieces made of aluminium alloy in terms of intersection the channel matrix at angles: $90^{\circ}, 90^{\circ}$ with a bending radius axis $R 30,120^{\circ}$.

Key words: equal channel angular pressing, stress, workpiece, normal force, bending moment.

Language: English

Citation: Chemezov DA (2015) COMPARATIVE ANALYSIS OF STRESS-STRAIN STATE OF WORKPIECES MADE OF ALUMINIUM ALLOY DURING OF THE EQUAL CHANNEL ANGULAR PRESSING PROCESS ACCORDING TO DIFFERENT SCHEMES. ISJ Theoretical \& Applied Science 07 (27): 52-64.

Soi: http://s-o-i.org/1.1/TAS-07-27-10 Doi: crossef http://dx.doi.org/10.15863/TAS.2015.07.27.10

The classic variant of the equal channel angular pressing (ECAP) process of metallic alloys is a forcing through workpiece of round or square crosssection through intersecting channels of the matrix at an angle of $90^{\circ}$. There are other variants ECAP is based on changing the configuration or angle of intersection of the channels of the matrix. Modernization of configuration is the smoothing of the abrupt transition at the intersection of the channels of the matrix. The angle of intersection of the receiving and output channels of the matrix it is recommended to choose in the range from $90^{\circ}$ to $150^{\circ}$.

To implement the process of ECAP process deformable non-ferrous alloys it is necessary to consider the physico-mechanical properties of materials and dimensions of the workpiece, the pressing speed (displacement of the punch in the receiving channel matrix), accuracy, strength and rigidity of the matrix and punch.

ECAP process is performed on all metal deformable plastic alloys: magnesium, nickel, aluminium, titanium, copper, steel, etc. In the works $[1,2,3,4,5,6]$ presents an assessment of stressstrain state of pressed under different conditions (without backpressure, with backpressure, pressing in cold and hot condition of the workpiece) metal alloys: Ti-6Al-4V, M1, ASME SA-738 CrA, AZ31,
1340. The workpieces was pressed at an angle of $90^{\circ}$. For titanium alloy plastic strain amounted more than 0.8 , the shear stress of more than $150 \mathrm{MPa}$, the principal stress of more than $300 \mathrm{MPa}$, the surface stress of more than $-500 \mathrm{MPa}$ (at action of negative values of the normal force and bending moment). Taking into account the action of backpressure, hydrostatic pressure in the deformation zone of copper workpiece amounted to more than $700 \mathrm{MPa}$ at a true strain of about 1.0 after one cycle of pressing. The plastic deformation of low-alloy steel (is heated to $500{ }^{\circ} \mathrm{C}$ ) leads to an increase of the strength characteristics 2.5 times compared with the initial state. ECAP process of magnesium alloy increases the yield strength and tensile strength deformed workpiece at 2.7 and 1.3 times, respectively. 1st principal stress reached a value of $350 \mathrm{MPa}$, 2nd principal stress of $248 \mathrm{MPa}$, 3rd principal stress $--237 \mathrm{MPa}$ in the result of ECAP process the aluminium alloy at an angle of $90^{\circ}$.

Aluminium alloys are used in aircraft industry, construction and mechanical engineering. Aluminium alloys are not inferior in strength titanium alloys at lower density The technique of pressing of aluminium alloys relative to other metals is at the highest level [7].

Analysis of stress-strain state of the material of the workpiece is pressed according to different 
schemes will identify the most efficient method by comparing the results of computer simulation of the ECAP process in three-dimensional setting.

The implementation of the simulation of the ECAP process was carried out in several stages. In a computer program KOMPAS-3D were constructed three-dimensional solid model matrices with receiving and output channels, intersecting at the following angles: $90^{\circ}, 90^{\circ}$ with a bending radius axis R30, $120^{\circ}$. The model of the pressed workpiece is located in the receiving channel of the matrix. The dimensions of the models matrices and the workpiece presents in Fig. 1.

The models were loaded in the module Explicit Dynamics software Ansys Workbench. For the accuracy of the calculation, on all models were constructed grid defines the number of elements (nodes). The selected matrix materials (steel alloy) and workpieces (aluminium alloy), given appropriate physico-mechanical properties. The matrix is not deformed, was a rigid body. Applied a constant load on the end surface of the workpiece. Formed contact conditions of ECAP process. All information for modeling of ECAP process the workpiece at an angle of $90^{\circ}$ presents below in text format.

\author{
*KEYWORD \\ *TITLE \\ ECAP \\ \$ Units: mm, mg, ms, mN, $\mathrm{K}$ \\ *DATABASE_FORMAT \\ \$ 1IFORM 2IBINARY \\ 0 \\ \$ NODE DEFINITIONS \\ *NODE \\ \$ 1NID 2X 3Y 4Z 5TC 6RC \\ $1,5.18016,1.4168,43.7638$ \\ 2, $10.1802,1.41679,43.7638$ \\ $3,15.1802,1.41679,43.7637$ \\ 4, 20.1802, 1.41678, 43.7637 \\ $5,25.1802,1.41678,43.7636$
}

$13781,-78.8417,-52.9097,85.7655$

$13782,-27.1867,78.5534,6.66382$

$13783,-7.37131,-66.6355,75.3602$

$13784,-10.529,-46.6353,28.3738$

$13785,-85.5565,80.4424,3.34854$

$\$$ ELEMENT DEFINITIONS

*ELEMENT_SOLID

$\$$ 1EID 2PID N1 N2 N3 N4 N5 N6 N7 N8

$1,1,12,23,34,45,112,113,114,115$

$2,1,12,45,34,23,13,46,35,24$

$3,1,13,46,35,24,14,47,36,25$

$4,1,14,47,36,25,15,48,37,26$

$5,1,15,48,37,26,16,49,38,27$

$164,1,95,106,205,168,96,107,204,172$

165, 1, 96, 107, 204, 172, 97, 108, 203, 176

$166,1,97,108,203,176,98,109,202,180$
$167,1,98,109,202,180,99,110,201,184$

$168,1,99,110,201,184,122,121,140,139$

*ELEMENT_SOLID

$\$$ 1EID 2PID N1 N2 N3 N4 N5 N6 N7 N8

169, 2, 395, 396, 1927, 1798, 1798, 1798, 1798, 1798

$170,2,555,3098,2851,556,556,556,556,556$

171, 2, 556, 2851, 2592, 3098, 3098, 3098, 3098, 3098

172, 2, 556, 2592, 3348, 3098, 3098, 3098, 3098, 3098

173, 2, 517, 3876, 3272, 3093, 3093, 3093, 3093, 3093

$66858,2,12129,13653,13072,12862,12862$, $12862,12862,12862$

$66859,2,11791,13653,13072,12129,12129$, $12129,12129,12129$

66860, 2, 11791, 13072, 13653, 12699, 12699, $12699,12699,12699$

66861, 2, 6564, 10143, 8344, 13659, 13659, 13659, 13659,13659

66862, 2, 5473, 8344, 6564, 10143, 10143, 10143, 10143,10143

$\$$ SECTION DEFINITIONS

*SECTION_SOLID

\$ 1SECID 2ELFORM 3AET

1,1

*SECTION_SOLID

$\$$ 1SECID 2ELFORM 3AET

2,13

$\$$ MATERIAL DEFINITIONS

*MAT_MODIFIED_PIECEWISE_LINEAR_PLAS TICITY

\$ 1MID 2RO 3E 4PR 5SIGY 6ETAN 7FAIL 8TDEL 1, 2.77, 7.1e+007, 0.33, 280000, 500000, 0

$\$ 1 \mathrm{C} 2 \mathrm{P}$ 3LCSS 4LCSR 5VP 6EPSTHIN 7EPSMAJ 8 NUMINT

$0,0,0$

\$ 1EPS1 2EPS2 3EPS3 4EPS4 5EPS5 6EPS6 7EPS7 8EPS8

$0,0,0,0,0,0,0,0$

\$ 1ES1 2ES2 3ES3 4ES4 5ES5 6ES6 7ES7 8ES8

$0,0,0,0,0,0,0,0$

*MAT_ELASTIC

\$ 1MID 2RO 3E 4PR 5DA 6DB 7K

$2,7.85,2 \mathrm{e}+008,0.3$

$\$$ PARTS DEFINITIONS

*PART

\$ HEADING

Part 1

\$ 1PID 2SECID 3MID 4EOSID 5HGID 6GRAV 7ADPORT 8TMID

$1,1,1,0,0$

*PART

$\$$ HEADING

Part 2

\$ 1PID 2SECID 3MID 4EOSID 5HGID 6GRAV 7ADPORT 8TMID 


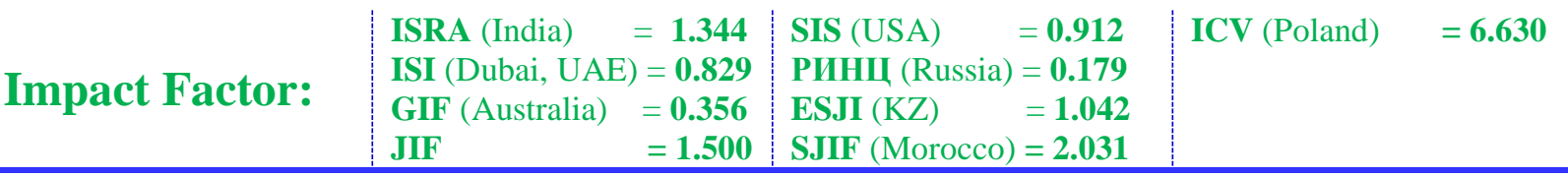

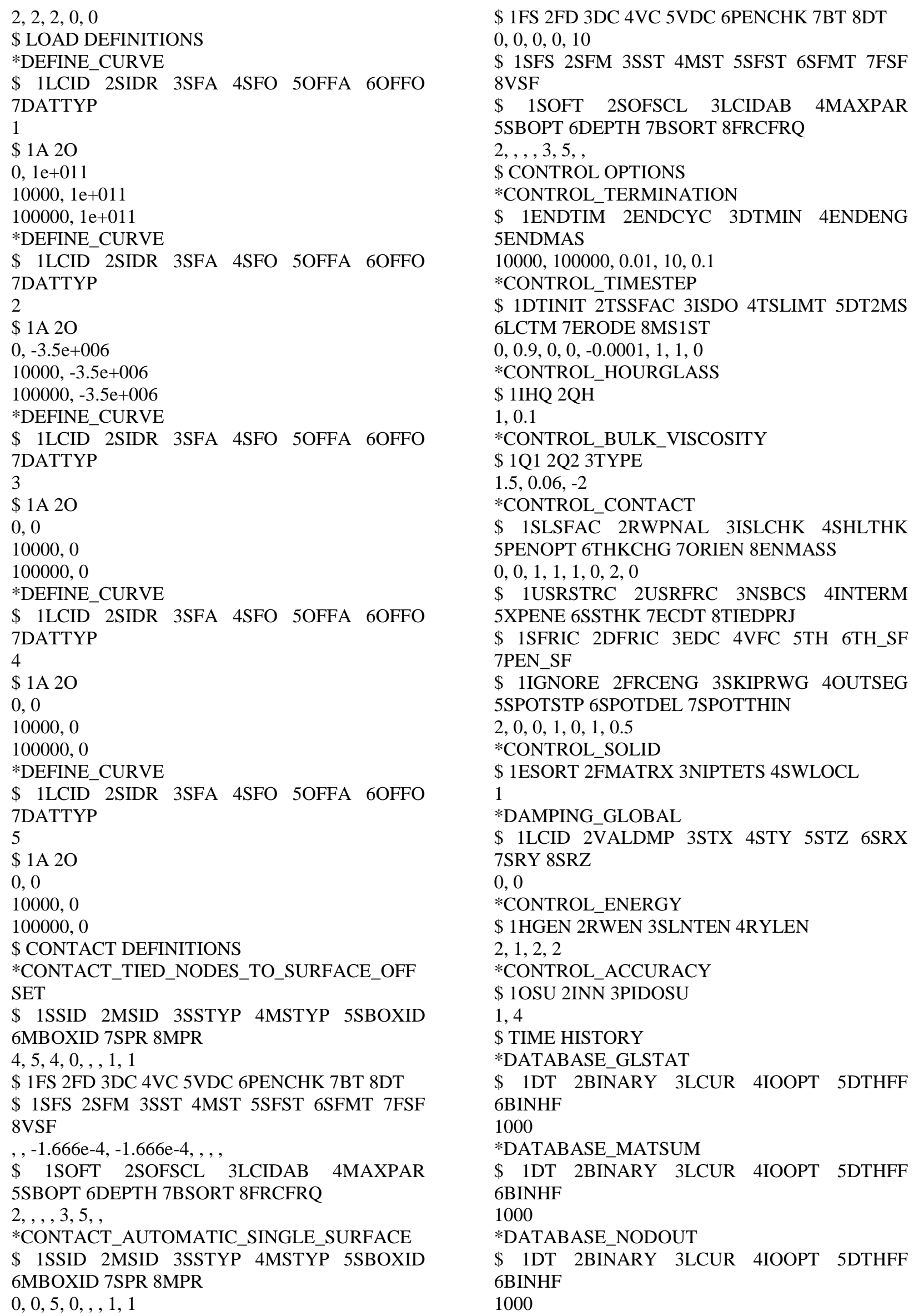

\$ 1FS 2FD 3DC 4VC 5VDC 6PENCHK 7BT 8DT $0,0,0,0,10$

$\$$ 1SFS 2SFM 3SST 4MST 5SFST 6SFMT 7FSF $8 \mathrm{VSF}$

$\$$ 1SOFT 2SOFSCL 3LCIDAB 4MAXPAR 5SBOPT 6DEPTH 7BSORT 8FRCFRQ

$2,,,, 3,5$, ,

$\$$ CONTROL OPTIONS

*CONTROL_TERMINATION

\$ 1ENDTIM 2ENDCYC 3DTMIN 4ENDENG 5ENDMAS

$10000,100000,0.01,10,0.1$

*CONTROL_TIMESTEP

\$ 1DTINIT 2TSSFAC 3ISDO 4TSLIMT 5DT2MS 6LCTM 7ERODE 8MS1ST

$0,0.9,0,0,-0.0001,1,1,0$

*CONTROL_HOURGLASS

\$1IHQ 2QH

$1,0.1$

*CONTROL_BULK_VISCOSITY

\$1Q1 2Q2 3TYPE

$1.5,0.06,-2$

*CONTROL_CONTACT

$\$$ 1SLSFAC 2RWPNAL 3ISLCHK 4SHLTHK 5PENOPT 6THKCHG 7ORIEN 8ENMASS

$0,0,1,1,1,0,2,0$

$\$$ 1USRSTRC 2USRFRC 3NSBCS 4INTERM 5XPENE 6SSTHK 7ECDT 8TIEDPRJ

\$ 1SFRIC 2DFRIC 3EDC 4VFC 5TH 6TH_SF 7PEN_SF

\$ 1IGNORE 2FRCENG 3SKIPRWG 4OUTSEG 5SPOTSTP 6SPOTDEL 7SPOTTHIN

$2,0,0,1,0,1,0.5$

*CONTROL_SOLID

\$ 1ESORT 2FMATRX 3NIPTETS 4SWLOCL

1

*DAMPING_GLOBAL

\$ 1LCID 2VALDMP 3STX 4STY 5STZ 6SRX 7SRY 8SRZ

0,0

*CONTROL_ENERGY

\$ 1HGEN 2RWEN 3SLNTEN 4RYLEN

$2,1,2,2$

*CONTROL_ACCURACY

$\$$ 1OSU 2INN 3PIDOSU

1,4

$\$$ TIME HISTORY

*DATABASE_GLSTAT

\$ 1DT 2BINARY 3LCUR 4IOOPT 5DTHFF 6BINHF

1000

*DATABASE_MATSUM

$\$$ 1DT 2BINARY 3LCUR 4IOOPT 5DTHFF 6BINHF

1000

*DATABASE_NODOUT

$\$$ 1DT 2BINARY 3LCUR 4IOOPT 5DTHFF 6BINHF

1000 
*DATABASE_ELOUT

\$ 1DT 2BINARY 3LCUR 4IOOPT 5DTHFF 6BINHF

1000

*DATABASE_BINARY_D3PLOT

\$ 1DT 2LCDT 3BEAM 4NPLTC

1000

*DATABASE_BINARY_RUNRSF

$\$ 1 D T 2 N R$

5000

$\$$ LIST SETS

*SET_NODE_LIST

\$ 1SID 2DA1 3DA2 4DA3 5DA4

1

\$ 1NID1 2NID2 3NID3 4NID4 5NID5 6NID6 7NID7 8NID8

261, 262, 263, 264, 265, 266, 267, 268

$271,272,273,274,275,276,269,270$

$277,278,279,280,281,282,283,284$

285, 286, 287, 288, 289, 290, 291, 292

293, 294, 295, 296, 297, 298, 299, 300

4805, 4806, 4807, 4808, 4809, 4810, 4811, 4812

$4813,4814,4815,4816,4817,4818,4819,4820$

$4821,4822,4823,4824,4825,4826,4827,4828$

$4829,4830,4831,4832,4833,4834,4835,4836$

4837, 4838

*SET_NODE_LIST

\$ 1SID 2DA1 3DA2 4DA3 5DA4

2

\$ 1NID1 2NID2 3NID3 4NID4 5NID5 6NID6 7NID7 8NID8

$121,122,123,124,125,126,127,128$

$131,132,133,134,135,136,129,130$

$137,138,139,140$

*SET_NODE_LIST

\$ 1SID 2DA1 3DA2 4DA3 5DA4

3

\$ 1NID1 2NID2 3NID3 4NID4 5NID5 6NID6 7NID7 8NID8

261, 298, 299, 300, 301, 302, 303, 304

$307,308,309,310,311,312,305,306$

$313,314,315,427,502,503,504,505$

506, 507, 508, 509, 510, 511, 512, 513

$514,515,516,517,518,519,520,521$

$3396,3397,3398,3399,3400,3401,3402,3403$

3404, 3405, 3406, 3407, 3408, 3409, 3410, 3411

$3412,3413,3414,3415,3416,3417,3418,3419$

$3420,3421,3422,3423,3424,3425,3426,3427$

$3428,3429,3430,3431$

*SET_NODE_LIST

\$ 1SID 2DA1 3DA2 4DA3 5DA4

4

\$ 1NID1 2NID2 3NID3 4NID4 5NID5 6NID6 7NID7 8NID8

$131,132,133,134,135,136,137,138$

$141,142,143,144,145,146,139,140$

$147,148,149,150,151,152,153,154$
$155,156,157,158,159,160,161,162$

$163,164,165,166,167,168,169,170$

$231,232,233,234,227,228,229,230$

$235,236,237,238,239,240,241,242$

243, 244, 245, 246, 247, 248, 249, 250

251, 252, 253, 254, 255, 256, 257, 258

259,260

*SET_SEGMENT

\$ 1SID 2DA1 3DA2 4DA3 5DA4

5

\$ 1N1 2N2 3N3 4N4 5A1 6A2 7A3 8A4

1891, 1892, 1938, 1938

1902, 1919, 1908, 1908

1925, 1925, 1900, 1937

$1888,1909,1928,1928$

$1897,1898,1937,1937$

$393,394,1884,1884$

$394,1849,1884,1884$

$378,379,1885,1885$

$379,1821,1885,1885$

$378,1885,1878,1878$

\$ BOUNDARY CONDITIONS

*LOAD_NODE_SET

\$ 1ID 2DOF 3LCID 4SF 5CID 6M1 7M2 8M3

2, 1, 2, 1.000, 0

*BOUNDARY_PRESCRIBED_MOTION_SET_ID

\$1 KeyID 2HEADING

1, Displacement

\$ 1ID 2DOF 3VAD 4LCID 5SF 6VID 7DEATH 8BIRTH

3, 1, 2, 3, 1.000, 0, 0, 0

*BOUNDARY_PRESCRIBED_MOTION_SET_ID

\$1 KeyID 2HEADING

2, Displacement

\$ 1ID 2DOF 3VAD 4LCID 5SF 6VID 7DEATH 8BIRTH

$3,2,2,4,1.000,0,0,0$

*BOUNDARY_PRESCRIBED_MOTION_SET_ID

\$1 KeyID 2HEADING

3, Displacement

\$ 1ID 2DOF 3VAD 4LCID 5SF 6VID 7DEATH 8BIRTH

3, 3, 2, 5, 1.000, 0, 0, 0

*BOUNDARY_SPC_SET

\$ 1NSID 2CID 3DOFX 4DOFY 5DOFZ 6DOFRX 7DOFRY 8DOFRZ

$1,0,1,1,1,1,1,1$

*END

Modeling of ECAP process was carried out in the program LS-DYNA. The results of the calculations are presented in the form of color contours on the model defining the stress-strain state of the workpiece (Fig. $2-4$ ). The contours were obtained at the time of movement of the workpiece from the receiving to the output channels of the matrix. 
The plastic strain of the material - irreversible deformation, caused by the change in stresses. The degree of plastic strain is determined by the deformation coefficient, i.e. the ratio of the sizes of the solid body after the deformation to the appropriate sizes before deformation [8].

The deviatoric stress - part of the stress tensor, obtained by subtracting from it the ball portion of this tensor. The deviatoric stress describes the change in shape of the deformed solid body without changing its volume [9].

1. The receiving and output channels intersect at an angle of $90^{\circ}$.

In accordance with the colors of the contours on the model, significant plastic deformation of the material (1.1) is observed on the contact surface of the workpiece at the transition of the receiving channel in the output matrix (Fig. 2, b). The plastic strain of the workpiece in the receiving channel is minimal.

In Fig. 2, c - e values of the maximum (1st) principal deviatoric stress of the material is positive (tension), the 2nd principal deviatoric stress positive and negative (tension and compression), the minimum (3rd) principal deviatoric stress is negative (compression). Defined maximum value: the $1 \mathrm{st}$ principal deviatoric stress of the material in the bend of the workpiece, the 2nd and 3rd principal deviatoric stresses around the end surface of the workpiece in the receiving channel.

2. The receiving and output channels intersect at an angle of $90^{\circ}$ with a bending radius axis R30.

The maximum plastic strain occurs on the end surface of the workpiece, facing to the punch (Fig. 3, b). The value of strain of the material amounted to 0.394. At the output channel, plastic strain of the material is reduced to 0.13 .

The maximum value of the 1 st principal deviatoric stress of the material (Fig. 3, c) is defined on the end surface, which receives the applied load, and the 3rd principal deviatoric stress - from the opposite end surface of the workpiece (Fig. 3, e). Significant 2nd principal deviatoric stress of the material concentrated is on the maximal bending radius of the workpiece in the channel matrix (Fig. 3, d).

3. The receiving and output channels intersect at an angle of $120^{\circ}$.

With increasing angle of intersection of the channels of the matrix, plastic strain of the material in the bend of the workpiece amounted to 0.61 . Significant plastic strain occurs in the layers of material in contact with the lower part of the outlet channel (Fig. 4, b).

Significant principal deviatoric stresses distributed by the volume of the workpiece: 1 st - in material, located in the output channel of the matrix (Fig. 4, c); 2nd - in the material, located in the receiving channel matrix (Fig. 4, d); 3rd - in local areas of the material located in the output channel of the matrix (Fig. 4, e).

The dependences of the normal force and bending moment from time pressing of the ECAP process presents in Fig. $5-7$.

The values of the normal force is negative, because there is a compression of the material of the workpiece from the load. With the exception of the alternating change of the normal force in the case of the ECAP process the workpiece in the matrix at the intersection of the channels at an angle of $90^{\circ}$ in the plane of the section $\mathrm{Y}$ and in the case of the ECAP process the workpiece in the matrix at the intersection of the channels at an angle of $120^{\circ}$ in the plane of the section $X$.

The maximum normal force, acting on the plane of the section $X$, amounted to $-0.16 \times 10^{9} \mathrm{mN}$ according to scheme No. 1 (Fig. 5, a).

The maximum normal force, acting on the plane of the section $\mathrm{Y}$, amounted to $-95 \times 10^{6} \mathrm{mN}$ according to scheme No. 3 (Fig. 7, b).

The maximum normal force, acting on the plane of the section $\mathrm{Z}$, amounted to $-0.425 \times 10^{9} \mathrm{mN}$ according to scheme No. 1 (Fig. 5, c).

The bending moment occurs as a result of changing the shape of the workpiece. The values of bending moment, for all schemes ECAP process, is positive, i.e., the moment acts in one direction.

The maximum bending moment, acting on the plane of the section $\mathrm{X}$, amounted to $0.23 \times 10^{9}$ $\mathrm{mN} \times \mathrm{mm}$ according to scheme No. 3 (Fig. 7, a).

The maximum bending moment, acting on the plane of the section $\mathrm{Y}$, amounted to $0.14 \times 10^{9}$ $\mathrm{mN} \times \mathrm{mm}$ according to scheme No. 3 (Fig. 7, b).

The maximum bending moment, acting on the plane of the section $\mathrm{Z}$, amounted to $1.79 \times 10^{9}$ $\mathrm{mN} \times \mathrm{mm}$ according to scheme No. 1 (Fig. 5, c).

Thus, the analysis of the results of computer simulation of ECAP process at different angles workpiece of aluminium alloy allows to make the following conclusions:

1. ECAP process the workpieces at the intersection of receiving and output channels of the matrix at an angle of $90^{\circ}$ with a bending radius axis $\mathrm{R} 30$ is the most rational way of pressing. This is evidenced the small plastic strain and stresses in the workpiece material, compared with other schemes ECAP process. The plastic strain of the workpiece material during ECAP process according to scheme No. 2 in 3 times less, than during ECAP process according to scheme No. 1. ECAP process according to scheme No. 1 is less efficient, requires significant pressure on the punch, which can entail to tool breakage.

2. The maximum normal forces and bending moments act in the plane of the section $\mathrm{Z}$ (along the axis of the workpiece). 


\begin{tabular}{|c|c|c|c|c|c|c|}
\hline Impact Factor: & $\begin{array}{l}\text { ISRA (India) } \\
\text { ISI (Dubai, UAE } \\
\text { GIF (Australia) } \\
\text { JIF }\end{array}$ & $\begin{array}{r}=1.344 \\
=0.829 \\
=0.356 \\
=1.500\end{array}$ & $\begin{array}{l}\text { SIS (USA) = } \\
\text { PИHЦ (Russia) = } \\
\text { ESJI (KZ) = } \\
\text { SJIF (Morocco) }\end{array}$ & $\begin{array}{l}=0.912 \\
=0.179 \\
=1.042 \\
=2.031\end{array}$ & ICV (Poland) & $=6.630$ \\
\hline
\end{tabular}

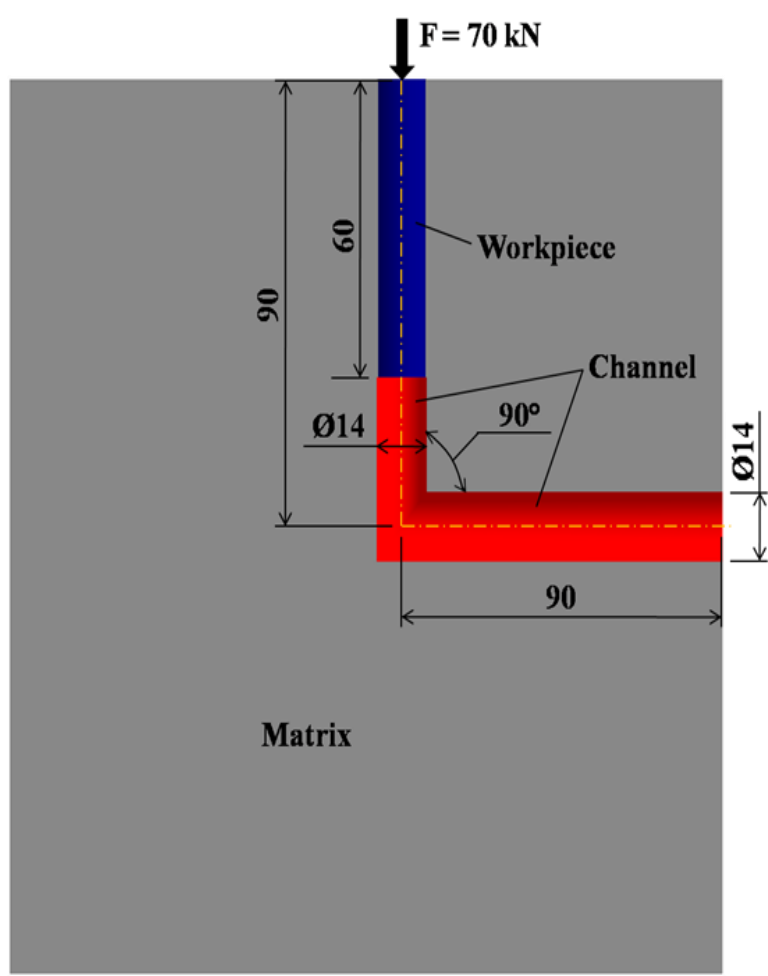

a)

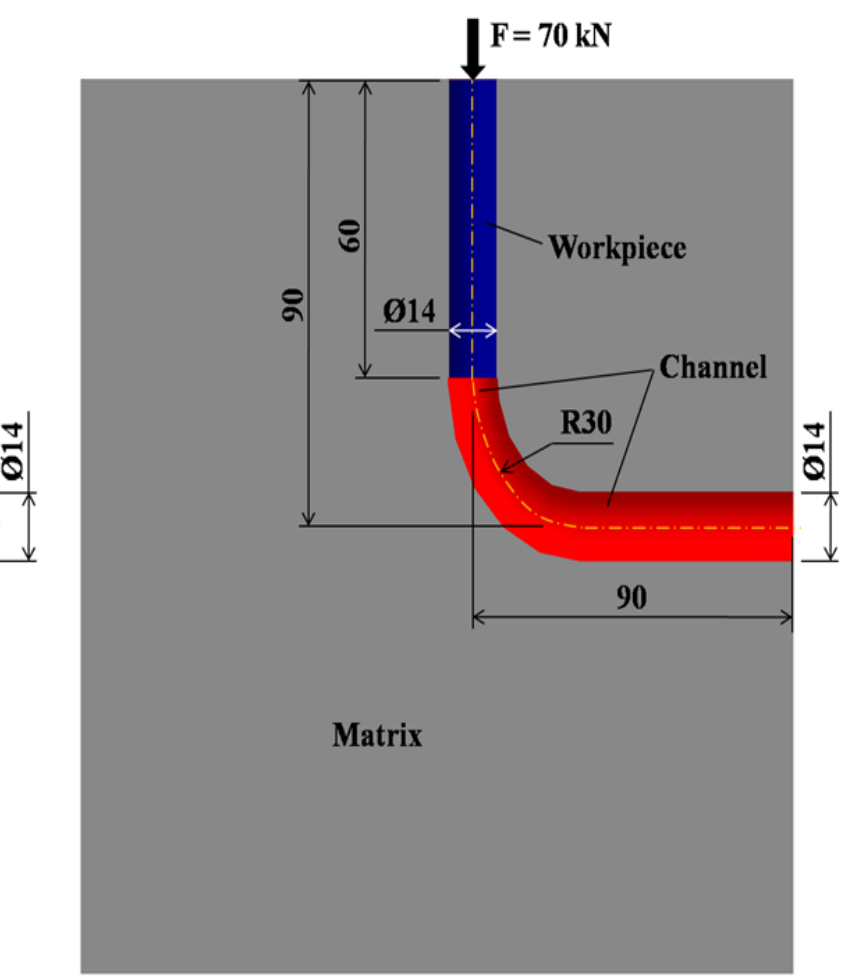

b)

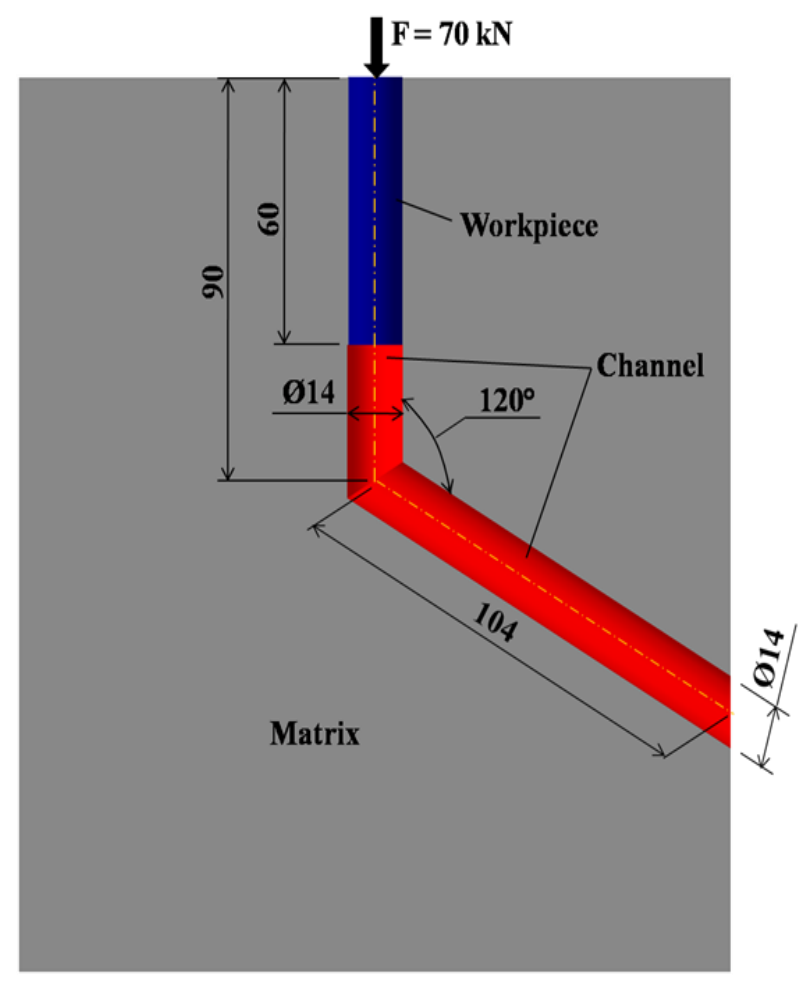

c)

Figure 1 - Schemes equal channel angular pressing process of the workpieces: a - the receiving and output channels intersect at an angle of $90^{\circ}$ (scheme No. 1); $b$ - the receiving and output channels intersect at an angle of $90^{\circ}$ with a bending radius axis $\mathrm{R30}$ (scheme No. 2); $\mathrm{c}$ - the receiving and output channels intersect at an angle of $120^{\circ}$ (scheme No. 3). 


\begin{tabular}{|c|c|c|c|c|c|c|}
\hline Impact Factor: & $\begin{array}{l}\text { ISRA (India) } \\
\text { ISI (Dubai, UAE } \\
\text { GIF (Australia) } \\
\text { JIF }\end{array}$ & $\begin{array}{l}=1.344 \\
=0.829 \\
=0.356 \\
=1.500\end{array}$ & $\begin{array}{l}\text { SIS (USA) } \\
\text { PUHЦ (Russia) } \\
\text { ESJI (KZ) } \\
\text { SJIF (Morocco) }\end{array}$ & $\begin{array}{l}=0.912 \\
=0.179 \\
=1.042 \\
=2.031\end{array}$ & ICV (Poland) & $=6.630$ \\
\hline
\end{tabular}

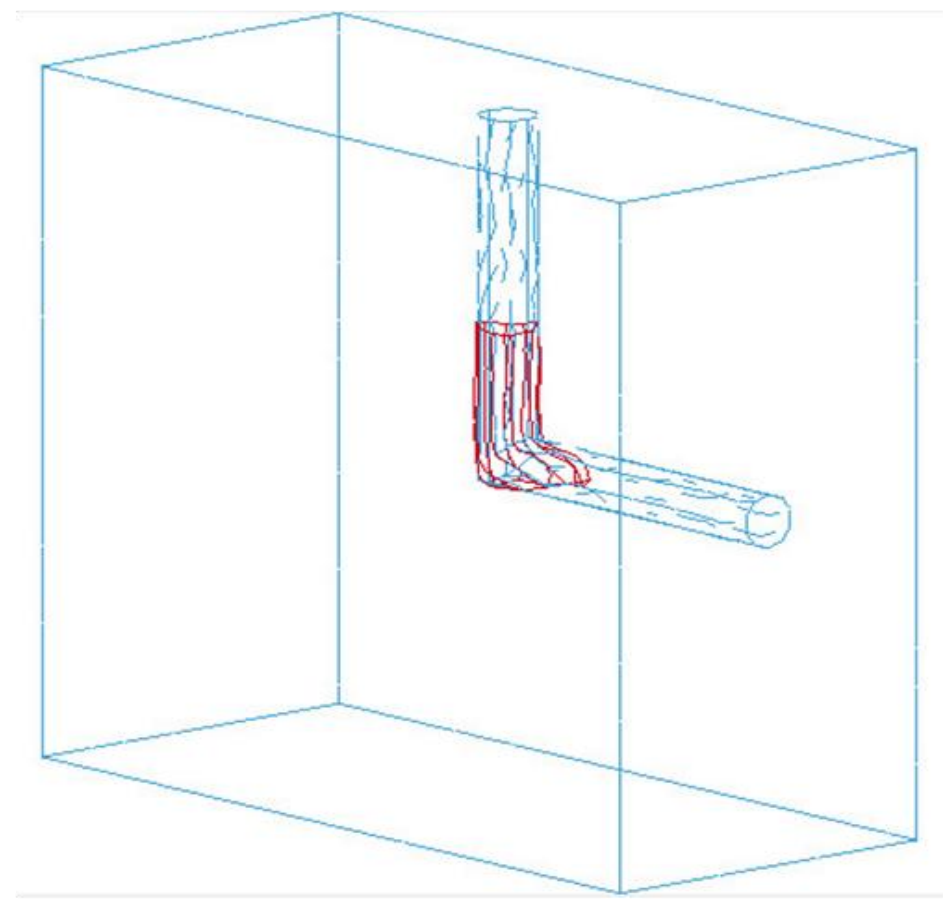

a)

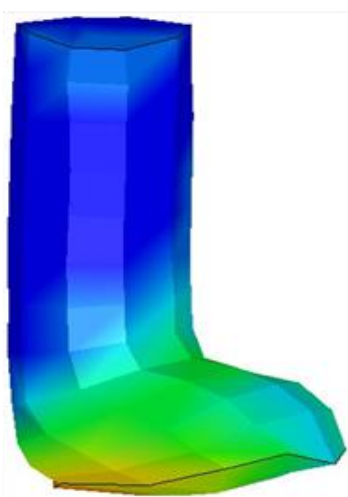

b)

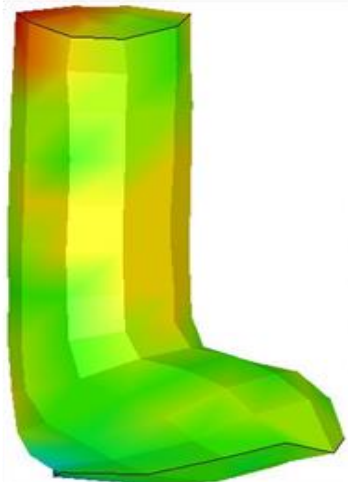

d)

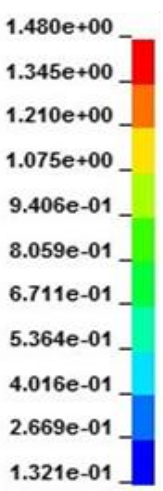

$1.271 e+05$

$9.256 e+04$

$5.799 e+04$

$2.342 e+04$

$-1.114 e+04$

$-4.571 e+04$

$-8.028 e+04$

$-1.149 \mathrm{e}+05$

$-1.494 \mathrm{e}+05$

$-1.840 e+05$

$-2.186 e+05$

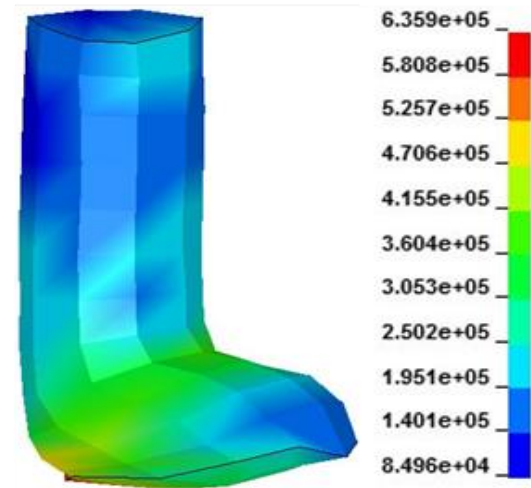

c)

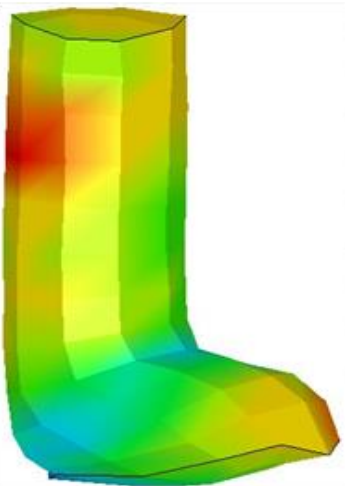

$-9.084 e+04$

$-1.310 \mathrm{e}+05$

$-1.712 e+05$

$-2.114 e+05$

$-2.516 e+05$

$-2.918 e+05$

$-3.320 \mathrm{e}+05$

$-3.722 e+05$

$-4.124 e+05$

$-4.526 e+05$

$-4.928 \mathrm{e}+05$

Figure 2 - The results of simulation of the equal channel angular pressing process of the workpiece in the matrix with intersection of the channels at an angle of $90^{\circ}$ (scheme No. 1): a - the location of the deformed workpiece in the channels; $b$ - contours of effective plastic strain; $c$ - contours of maximum principal deviatoric stress; $d$ - contours of 2 nd principal deviatoric stress; $\mathrm{e}$ - contours of minimum principal deviatoric stress. Units: $\mathrm{mm}, \mathrm{mg}, \mathrm{ms}, \mathrm{mN}, \mathrm{K}$. 


\begin{tabular}{|c|c|c|c|c|c|c|}
\hline Impact Factor: & $\begin{array}{l}\text { ISRA (India) } \\
\text { ISI (Dubai, UAE } \\
\text { GIF (Australia) } \\
\text { JIF }\end{array}$ & $\begin{array}{l}=1.344 \\
=0.829 \\
=0.356 \\
=1.500\end{array}$ & $\begin{array}{l}\text { SIS (USA) } \\
\text { PИНЦ (Russia) } \\
\text { ESJI (KZ) } \\
\text { SJIF (Morocco) }\end{array}$ & $\begin{array}{l}=0.912 \\
=0.179 \\
=1.042 \\
=2.031\end{array}$ & ICV (Poland) & $=6.630$ \\
\hline
\end{tabular}

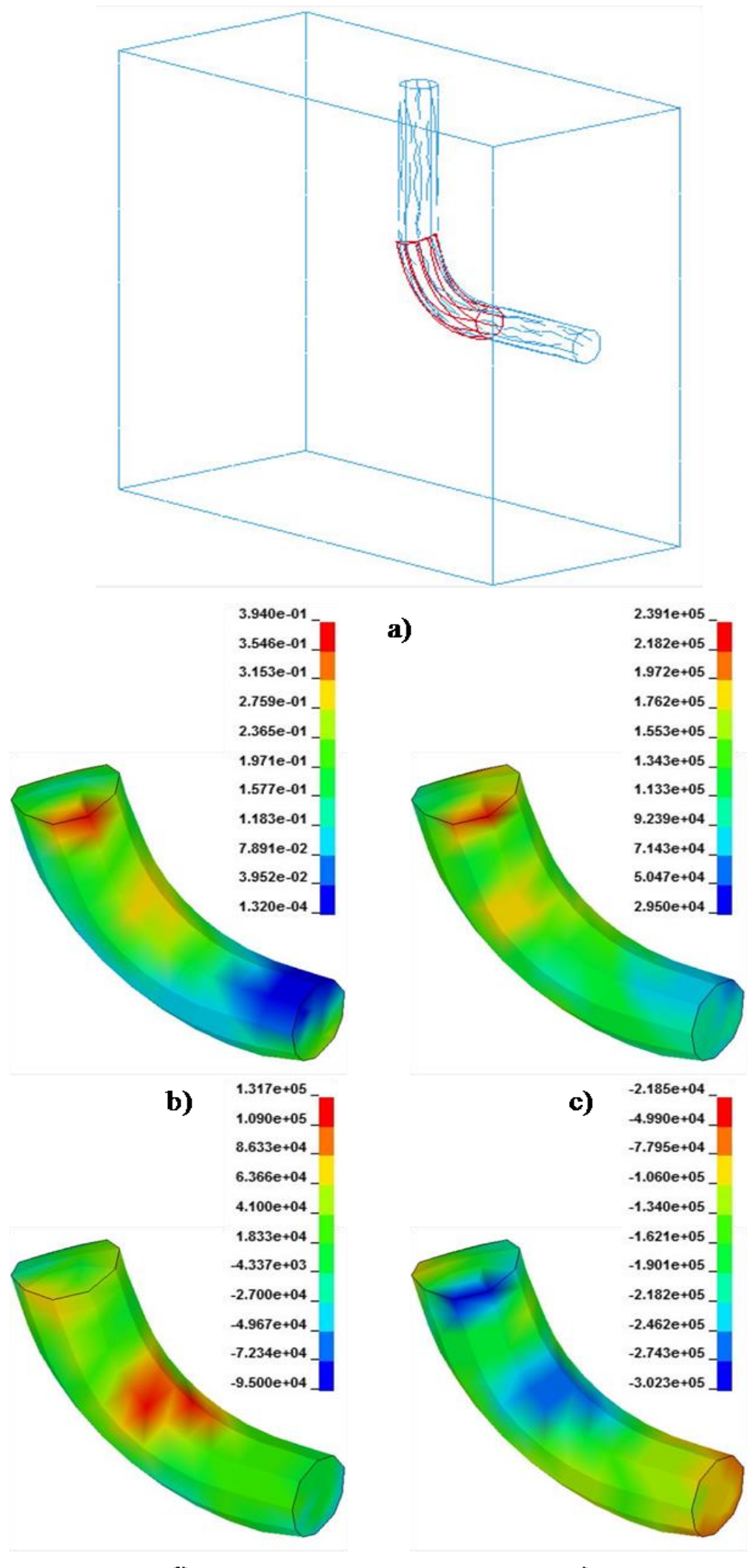

d)

e)

Figure 3 - The results of simulation of the equal channel angular pressing process of the workpiece in the matrix with intersection of the channels at an angle of $90^{\circ}$ with a bending radius axis R30 (scheme No. 2): a the location of the deformed workpiece in the channels; $b$ - contours of effective plastic strain; $c$ - contours of maximum principal deviatoric stress; $d$ - contours of 2 nd principal deviatoric stress; $e$ - contours of minimum principal deviatoric stress. Units: $\mathbf{m m}, \mathbf{m g}, \mathrm{ms}, \mathrm{mN}, \mathrm{K}$.

ISPC Intelligent technologies, 


\begin{tabular}{|c|c|c|c|c|c|c|}
\hline Impact Factor: & $\begin{array}{l}\text { ISRA (India) } \\
\text { ISI (Dubai, UAE } \\
\text { GIF (Australia) } \\
\text { JIF }\end{array}$ & $\begin{array}{l}=1.344 \\
=0.829 \\
=0.356 \\
=1.500\end{array}$ & $\begin{array}{l}\text { SIS (USA) } \\
\text { PUHЦ (Russia) } \\
\text { ESJI (KZ) } \\
\text { SJIF (Morocco) }\end{array}$ & $\begin{array}{l}=0.912 \\
=0.179 \\
=1.042 \\
=2.031\end{array}$ & ICV (Poland) & $=6.630$ \\
\hline
\end{tabular}

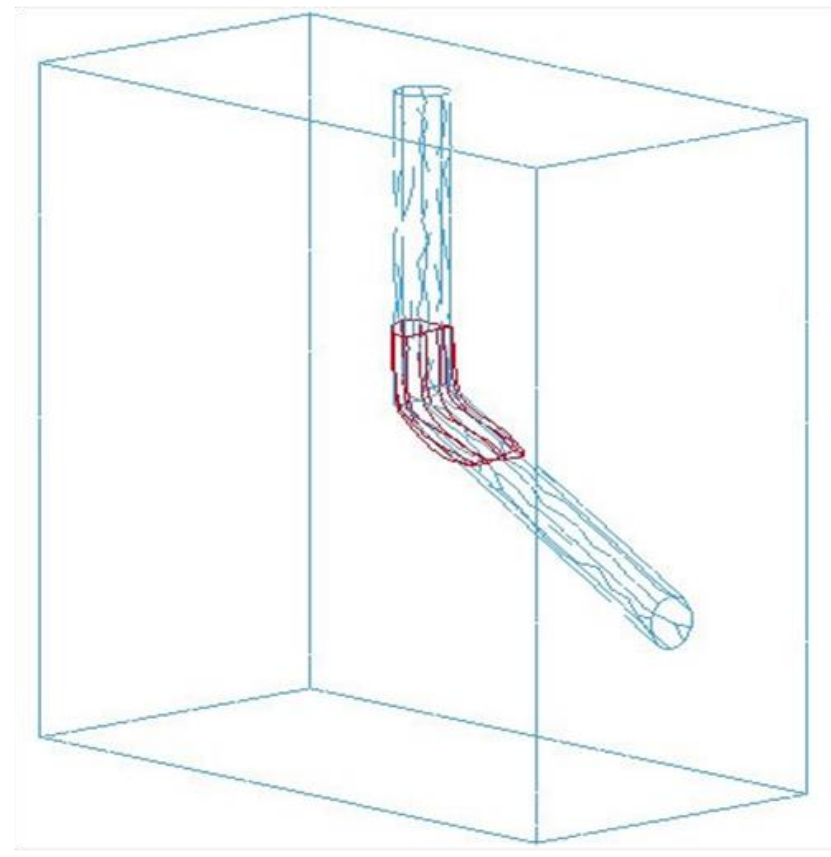

a)

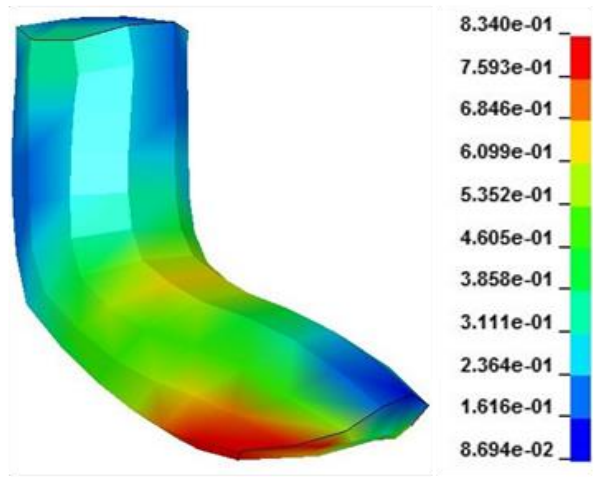

b)

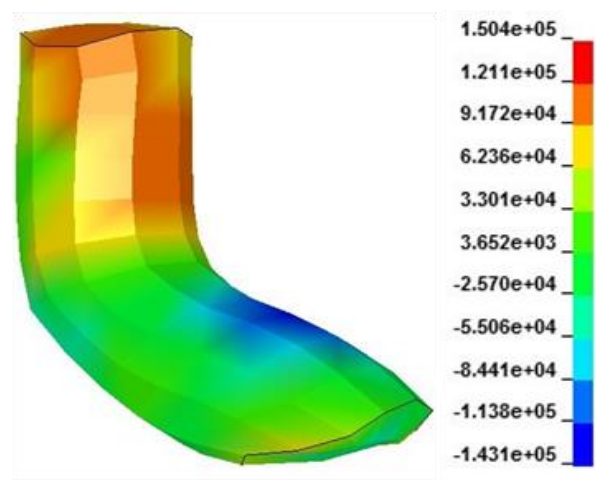

d)

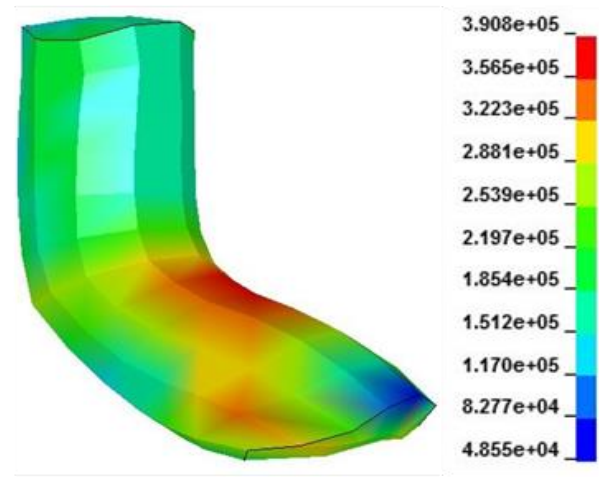

c)

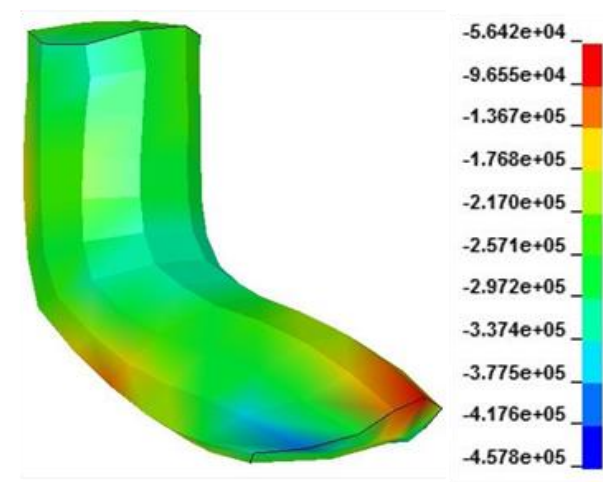

e)

Figure 4 - The results of simulation of the equal channel angular pressing process of the workpiece in the matrix with intersection of the channels at an angle of $120^{\circ}$ (scheme No. 3): a - the location of the deformed workpiece in the channels; $b$ - contours of effective plastic strain; $c$-contours of maximum principal deviatoric stress; $d$ - contours of 2 nd principal deviatoric stress; $\mathrm{e}$ - contours of minimum principal deviatoric stress. Units: $\mathbf{m m}, \mathbf{m g}, \mathbf{m s}, \mathbf{m N}, \mathrm{K}$. 


\begin{tabular}{|c|c|c|c|c|c|c|}
\hline Impact Factor: & $\begin{array}{l}\text { ISRA (India) } \\
\text { ISI (Dubai, UAE } \\
\text { GIF (Australia) } \\
\text { JIF }\end{array}$ & $\begin{array}{l}=1.344 \\
=0.829 \\
=0.356 \\
=1.500\end{array}$ & $\begin{array}{l}\text { SIS (USA) = } \\
\text { PUHЦ (Russia) = } \\
\text { ESJI (KZ) = } \\
\text { SJIF (Morocco) }\end{array}$ & $\begin{array}{l}=0.912 \\
=0.179 \\
=1.042 \\
=2.031\end{array}$ & ICV (Poland) & $=6.630$ \\
\hline
\end{tabular}
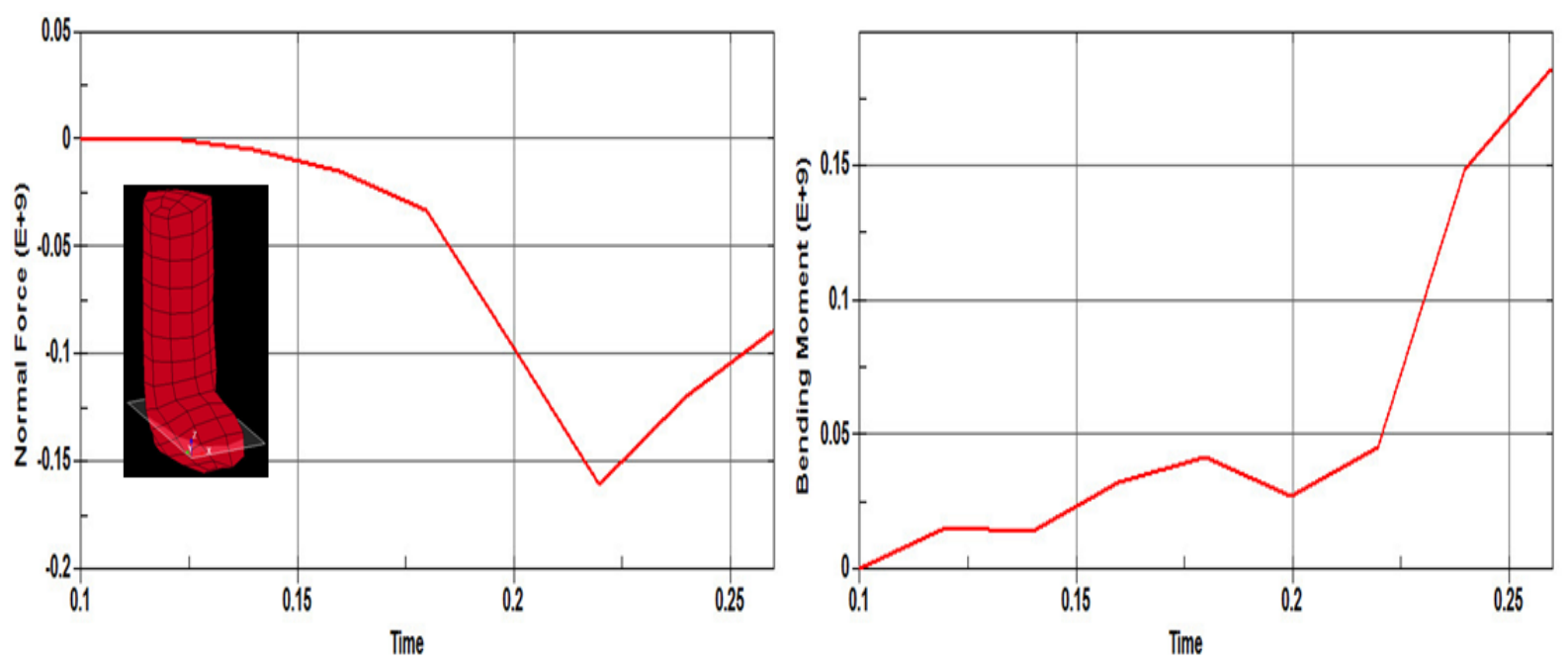

a)
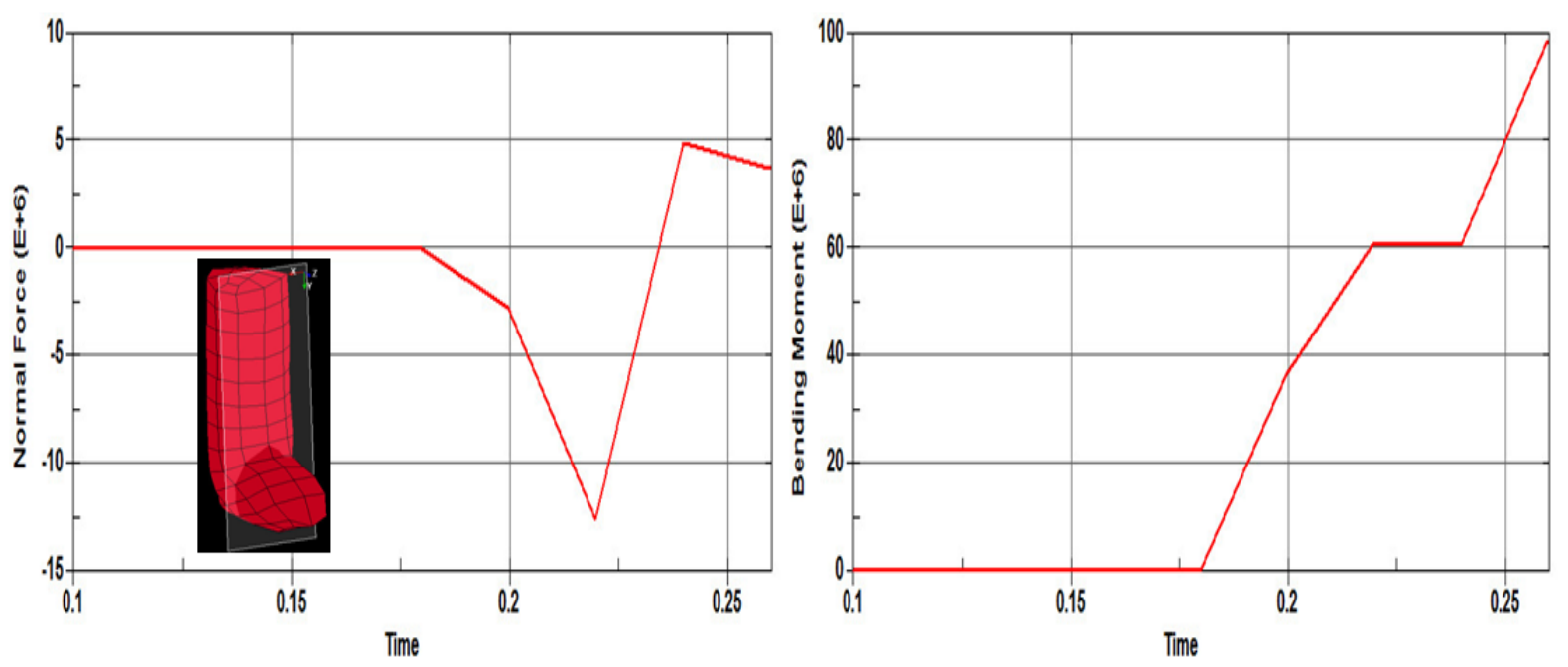

b)
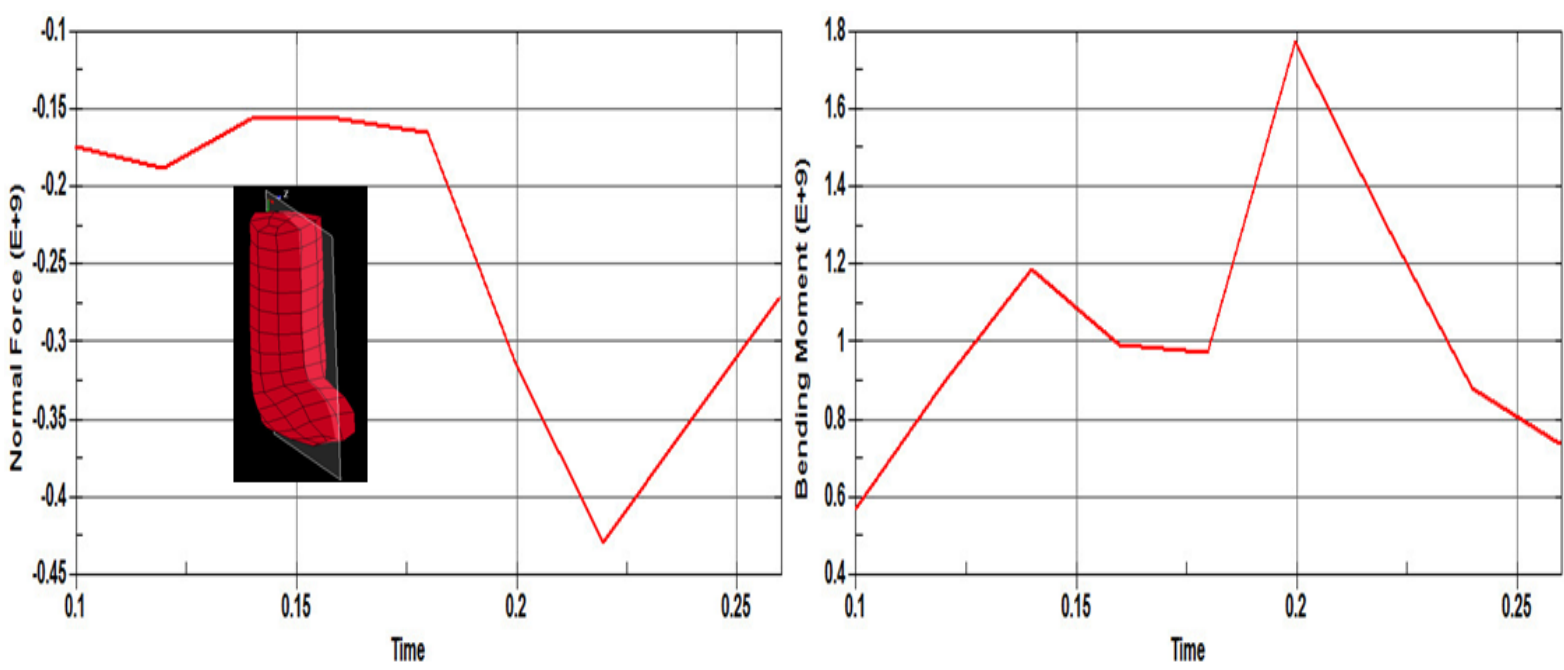

c)

Figure 5 - The dependences of the normal force and bending moment from the time of the equal channel angular pressing process of the workpiece according to scheme No. 1: a - the plane of the section X; $b$ - the plane of the section $\mathrm{Y}$; $\mathrm{c}$ - the plane of the section Z. Units: $\mathbf{m m}, \mathrm{mg}, \mathrm{ms}, \mathrm{mN}, \mathrm{K}$. 


\begin{tabular}{|c|c|c|c|c|c|c|}
\hline Impact Factor: & $\begin{array}{l}\text { ISRA (India) } \\
\text { ISI (Dubai, UAE } \\
\text { GIF (Australia) } \\
\text { JIF }\end{array}$ & $\begin{array}{l}=1.344 \\
=0.829 \\
=0.356 \\
=1.500\end{array}$ & $\begin{array}{l}\text { SIS (USA) = } \\
\text { PUHЦ (Russia) = } \\
\text { ESJI (KZ) = } \\
\text { SJIF (Morocco) }\end{array}$ & $\begin{array}{l}=0.912 \\
=0.179 \\
=1.042 \\
=2.031\end{array}$ & ICV (Poland) & $=6.630$ \\
\hline
\end{tabular}
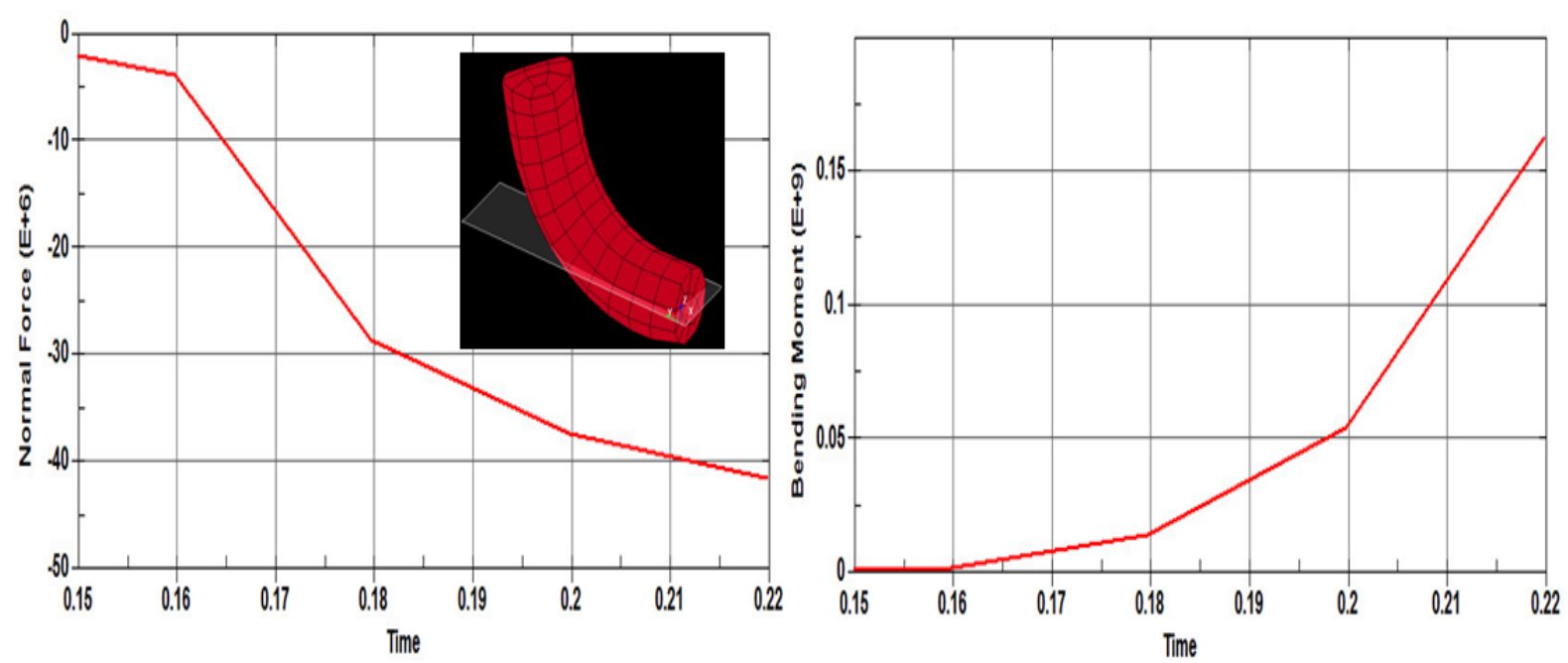

a)
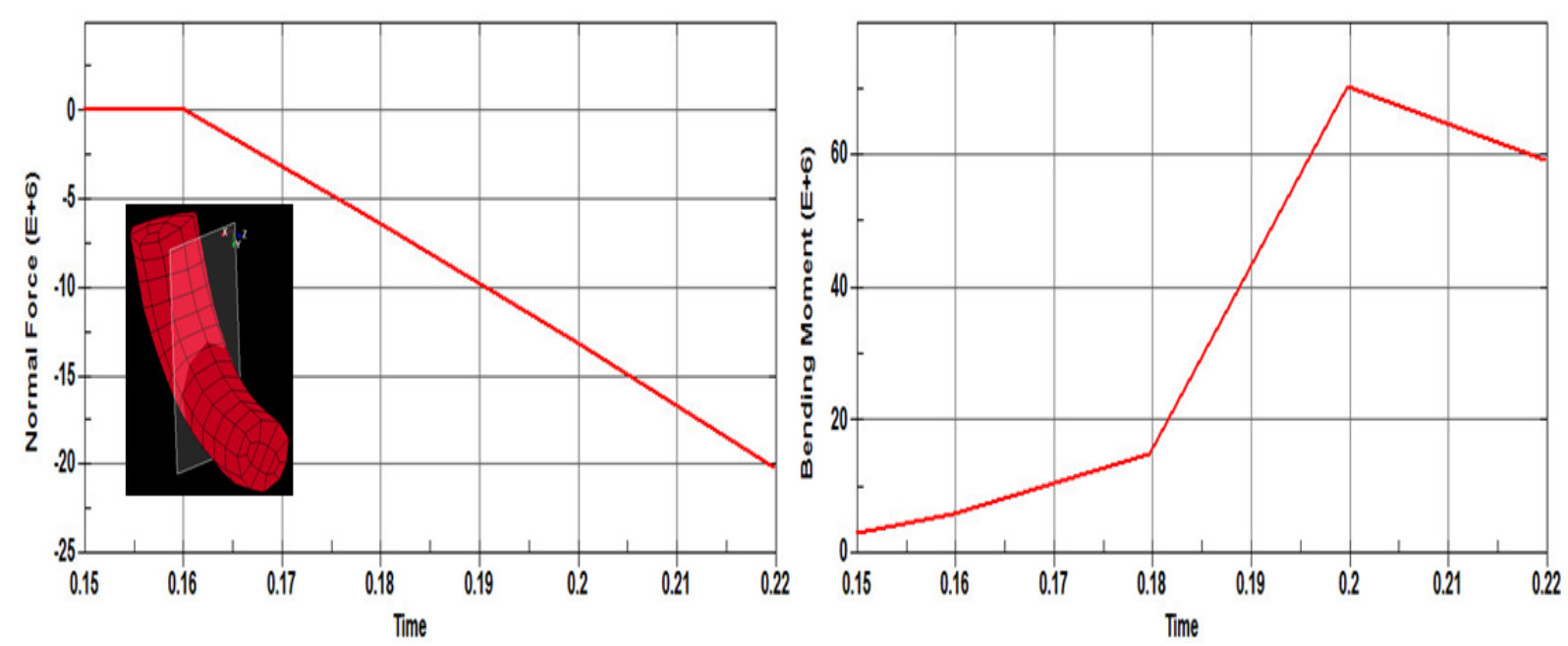

b)
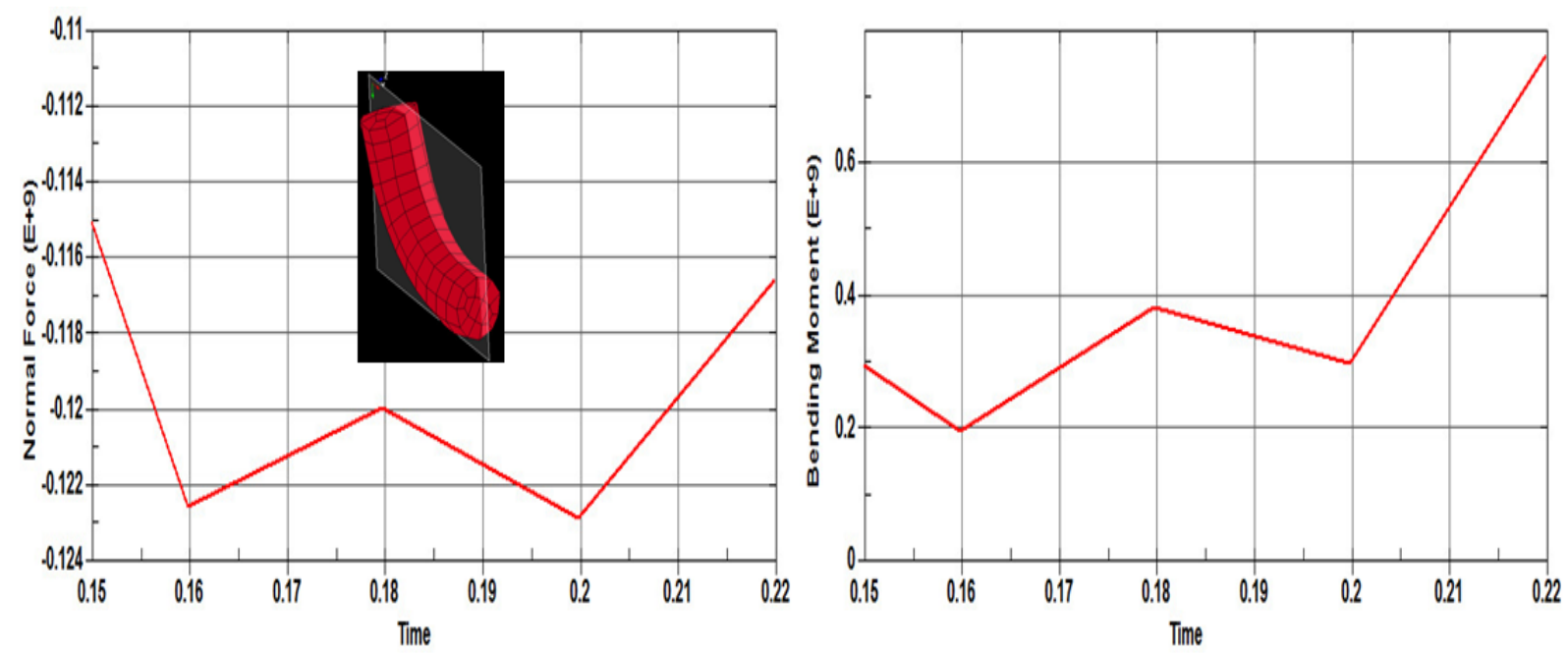

c)

Figure 6 - The dependences of the normal force and bending moment from the time of the equal channel angular pressing process of the workpiece according to scheme No. 2: a - the plane of the section X; $b$ - the plane of the section $\mathrm{Y}$; $\mathrm{c}$ - the plane of the section $\mathrm{Z}$. Units: $\mathrm{mm}, \mathrm{mg}, \mathrm{ms}, \mathrm{mN}, \mathrm{K}$.

ISPC Intelligent technologies,

Marseille, France 


\begin{tabular}{|c|c|c|c|c|c|c|}
\hline Impact Factor: & $\begin{array}{l}\text { ISRA (India) } \\
\text { ISI (Dubai, UAF } \\
\text { GIF (Australia) } \\
\text { JIF }\end{array}$ & $\begin{array}{r}=1.344 \\
=0.829 \\
=0.356 \\
=1.500\end{array}$ & $\begin{array}{l}\text { SIS (USA) } \\
\text { PИНЦ (Russia) } \\
\text { ESJI (KZ) } \\
\text { SJIF (Morocco) }\end{array}$ & $\begin{array}{l}=0.912 \\
=0.179 \\
=1.042 \\
=2.031\end{array}$ & ICV (Poland) & $=6.630$ \\
\hline
\end{tabular}
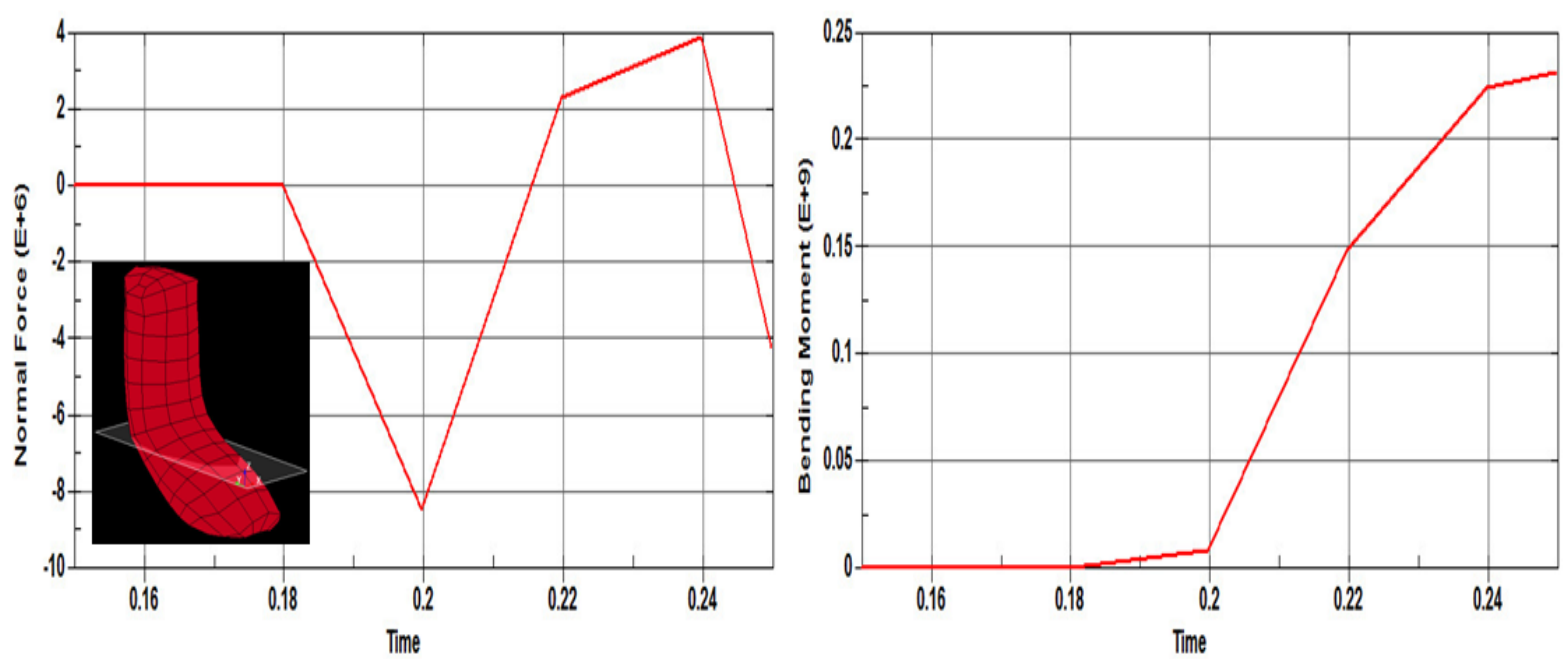

a)
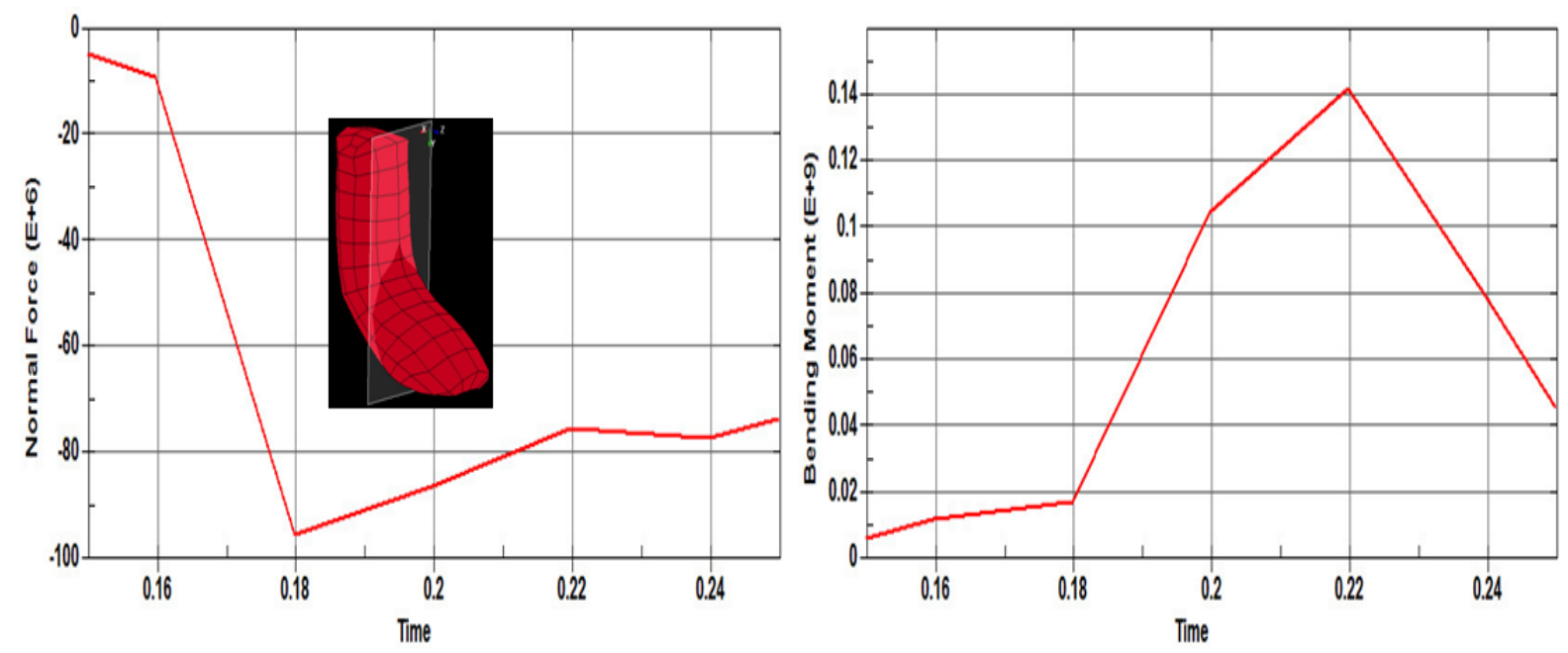

b)
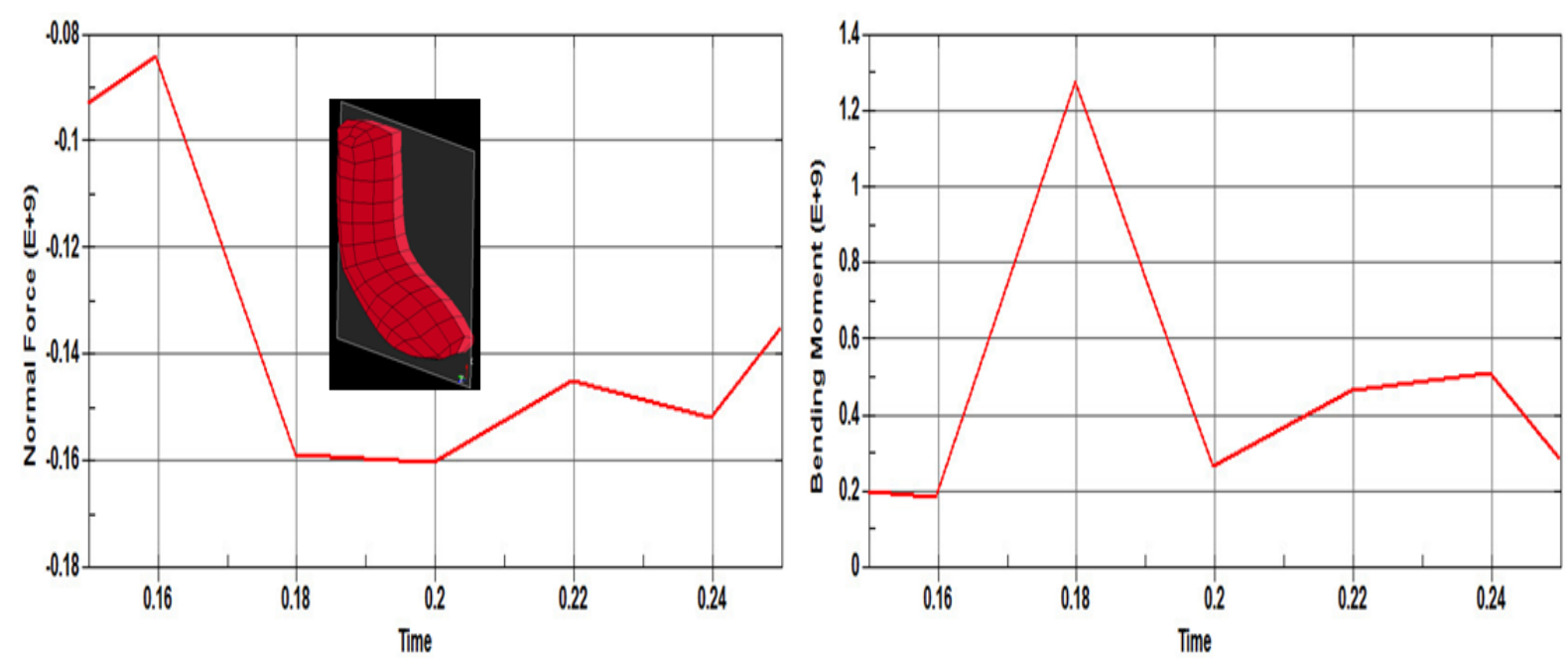

c)

Figure 7 - The dependences of the normal force and bending moment from the time of the equal channel angular pressing process of the workpiece according to scheme No. 3: a - the plane of the section $X ; b$ - the plane of the section Y; $\mathrm{c}$ - the plane of the section Z. Units: $\mathrm{mm}, \mathrm{mg}, \mathrm{ms}, \mathrm{mN}, \mathrm{K}$.

ISPC Intelligent technologies,

Marseille, France 


\begin{tabular}{|c|c|c|c|c|c|c|}
\hline Impact Factor: & $\begin{array}{l}\text { ISRA (India) } \\
\text { ISI (Dubai, UAF } \\
\text { GIF (Australia) } \\
\text { JIF }\end{array}$ & $\begin{array}{l}=1.344 \\
=\mathbf{0 . 8 2 9} \\
=\mathbf{0 . 3 5 6} \\
=1.500\end{array}$ & $\begin{array}{l}\text { SIS (USA) } \\
\text { PИHЦ (Russia) } \\
\text { ESJI (KZ) } \\
\text { SJIF (Morocco) }\end{array}$ & $\begin{array}{l}=0.912 \\
=0.179 \\
=1.042 \\
=2.031\end{array}$ & ICV (Poland) & $=6.630$ \\
\hline
\end{tabular}

\section{References:}

1. Chemezov DA, Bayakina AV (2015) The intensity of stress \& strain of the model, which is made of titanium alloy $\mathrm{Ti}-6 \mathrm{Al}-4 \mathrm{~V}$, during equal channel angular pressing. ISJ Theoretical \& Applied Science 04 (24): 74-79. Soi: http://so-i.org/1.1/TAS*04(24)13 Doi: http://dx.doi.org/10.15863/TAS.2015.04.24.13

2. Chemezov DA, Bayakina AV, Bayakina ED (2015) Surface stress model made of Ti- 6Al$4 \mathrm{~V}$ alloy processed by equal channel angular pressing. ISJ Theoretical \& Applied Science 05 (25): 54-58. Soi: $\underline{\text { http://s-o- }}$ i.org/1.1/TAS*05(25)11 Doi: http://dx.doi.org/10.15863/TAS.2015.05.25.11

3. Raab GI, Makarychev KN, Valiev RZ (2005) Features of the stressed-strained state during the equal-channel angular pressing with backpressure. Scientific Journal High pressure physics and technics Vol. 15, No. 1, 2005. - pp. 72 - 80. ISSN 0868-5924.

4. Yakovleva SP, Makharova SN (2014) Autocorrelation functions of the deformation surface profile of the low-alloyed steel in coarse-grained and nanostructured states.
Scientific journal Fundamental research No. 11, 2014. - pp. 1015 - 1020.

5. Skryabina NE, Aptukov VN, Romanov PV, Fruchart D (2014) Impact of equal-channel angular pressing on mechanical behavior and microstructure of magnesium alloys. PNRPU Mechanics Bulletin. 2014. No. 3. pp. 113-128. DOI: http://10.15593/perm.mech/2014.3.07

6. Chemezov DA (2015) Modelling and analysis of process of equal-channel angular pressing of metal alloys. International peer reviewed science journal New University. Technical sciences. 5-6 (39-40) 2015. - pp. 42 - 52. ISSN $2221-9552$.

7. (2015) Osobennosti pressovaniya razlichnyh splavov. Available: http://www.stroitelstvonew.ru/pressovanie/osobennosti.shtml (Accessed: 12.07.2015).

8. (2015) Teoriya OMD. Available: http://anybook.org/download/18120.html (Accessed: 12.07.2015).

9. (2015) Deviator napryajeniy. Available: http://www.manual-steel.ru/term7881.html (Accessed: 12.07.2015). 